\title{
Seu tema livre poderá ser um artigo do Jornal Vascular Brasileiro
}

\author{
Free papers can be a Jornal Vascular Brasileiro's article
}

Guilherme Benjamin Brandão Pitta*

Entre 21 e 25 de setembro de 2009, receberemos no XXXVIII Congresso Brasileiro de Angiologia e Cirurgia Vascular, em Maceió (AL), os angiologistas e cirurgiões vasculares do Brasil e do mundo, para nos atualizarmos, discutirmos e aprendermos sobre a nossa especialidade. Contamos com a presença de todos para comemorar 30 anos do último congresso em Maceió, que teve a participação de 500 sócios, comandado pelo inesquecível Dr. Dirceu Falcão, que foi o primeiro presidente alagoano da nossa antiga SBA (Sociedade Brasileira de Angiologia), hoje a moderna SBACV (Sociedade Brasileira de Angiologia e de Cirurgia Vascular).

Gostaríamos, também, de reiterar nosso orgulho pelo Jornal Vascular Brasileiro, que está reformulado, atualizado e em plena atuação na divulgação da nossa especialidade, com a publicação de artigos científicos que ensinam, orientam e ajudam todos na melhoria do atendimento de pacientes com doenças vasculares. Para firmar-se como revista de impacto, é preciso que os temas livres enviados para o nosso congresso, além dos temas livres especiais, orais e painéis (pôsteres), sejam transformados em artigos publicados ${ }^{1}$. Os temas livres correlatos com as palestras principais do congresso serão de importância crucial, pelo grande potencial de se transformarem em artigos originais especiais publicados em nossa revista científica. Para incentivar as publicações, os autores de artigos originais completos oriundos de temas livres deste congresso aprovados pelos revisores do Jornal Vascular Brasileiro terão como um dos prêmios a isenção de inscrição no nosso congresso. Premiaremos, da mesma forma, os melhores temas livres. As palestras serão publicadas nos anais do congresso em meio impresso e digital, e os temas livres especiais, correlatos e orais serão publicados em um suplemento especial da nossa revista, editado especialmente para o XXXVIII Congresso Brasileiro de Angiologia e Cirurgia Vascular. Tal congresso pretende ser participativo, com amplo espaço para discussão com os colegas palestrantes, com pelo menos 30 minutos nas mesas-redondas e $10 \mathrm{mi}-$ nutos nas palestras, sem mencionar a participação ativa que todos podem ter nos simpósios, cursos pré-congresso e nos temas livres, orais e pôsteres.

Os temas centrais do congresso foram escolhidos através de pesquisa com os associados, buscando atender a vontade de todos, e serão discutidos por convidados nacionais e estrangeiros da maior competência e qualidade. Acessem a página do congresso (http://www.maceio2009.com.br) a fim de obter todas as informações e conhecer em detalhes o evento oficial da nossa sociedade. Acreditamos que teremos a participação de mais de 2.000 associados, sendo este hoje um dos maiores eventos do mundo na especialidade.

Espero todos em Maceió.

\section{Referência}

1. Yoshida WB. Temas livres versus publicação. J Vasc Bras. 2005;4:319-20.

\footnotetext{
* Presidente, XXXVIII Congresso Brasileiro de Angiologia e Cirurgia Vascular da SBACV - "Congresso para todos".

Não foram declarados conflitos de interesse associados à publicação deste editorial. 